\title{
Válogatott rövid esszék Charles Csuritól
}

\section{A STATISZTIKA MINT INTERAKTÍV MÜTÁRGY}

A KÉPZELET BARANGOLÁSAI

VIRTUÁLIS OBJEKTUMOK SZANATÓRIUMA

KITAPINTHATÓ MOZGÁSÉRZÉKELÉS

VISSZATEKINTÉSEK, TŰNŐDÉSEK, ARS POETICÁK (interjúk Charles Csurival)

\section{Szerzői információ:}

Charles (Chuck) Csuri

1922-ben született a nyugat-virginiai Grant Townban, szülei Szeged mellól vándoroltak ki az Egyesült Államokba. 1947-tól 1949-ig az Ohio State University sportösztöndíjas hallgatója volt a múvészeti fakultáson. 1955 és 1965 között festményei elkezdtek megjelenni New York-i kiállításokon, ezzel párhuzamosan ívelt fel egyetemi karrierje. Az általa létrehívott Advanced Computing Center for the Arts and Design (ACCAD) vezetójeként nevéhez füződik az Ohio Supercomputer Graphics Project (OSGP) elindítása. Az egyetemi kutatómunka miatt egy idôre háttérbe szoruló alkotótevékenységének újjáéledését 1986-ban a 42. velencei biennálén elért nagy sikerek, majd 1989-ben és 90-ben a linzi Ars Electronica fesztiválon bemutatott díjnyertes alkotások jelzik. A csúcs: önálló kiállítás a Smithsonian Intézetben, 1990-ben. Alkotásait hetvenöt múzeum és számos ismert, komoly magángyúijtemény ôrzi.

Így hivatkozzon erre a cikkre:

Csuri, Charles. „Válogatott rövid esszék Charles Csuritól.”

Információs Társadalom IX, 1. szám (2009): 10-30. 


\section{Charles Csuri: A statisztika mint interaktív mütárgy' (1975)}

A múvészek sokszor használták fel a természet (a környezetból vett „valós adatok") közvetlen elemzését múalkotásaik létrehozásakor. Az egyik példa erre Monet, aki egyenesen a természet után festett, s a színek és a fény közötti kapcsolatok megjelenítésében új színelméletekre támaszkodott. Cézanne múvészete is a színek formális kapcsolatait juttatja kifejezésre súrített formában, külsó tárgyak vagy jelenetek által inspirálva. Más múvészek - köztük Picasso, Duchamp, majd az 1950-es évek közepén és a korai 60-as években Rauschenberg és Segal - konkrét tárgyakat használtak fel múveik megalkotásához. Múalkotássá tették például egy bicikli nyergét vagy egy autó ajtaját, de az ố kezükben új kontextust teremthetett a múvészi kifejezés számára egy szék vagy egy Coca-Cola-automata is, más tárgyi elemekkel kombinálva. Kaprow happeningjei, amelyek már a környezet egészét és a társadalmat is bevonták a múvészet körébe, világosan jelezték a „valós adatok” felhasználásának további kiterjesztését. A konceptuális múvészet (concept art) mozgalma ismét más módszereket hozott, és új felfogást hirdetett a tárgyak, az absztrakció és általában a múvészet tekintetében egyaránt: tervrajzokhoz használt nagyméretú másolópapírra szabványbetúkkel nyomtatva például egy kéz fizikai jellemzóit felsoroló szavak a kéz mentális képét idézik fel: itt a „tervrajz” és maguk a szavak válnak mứalkotássá.

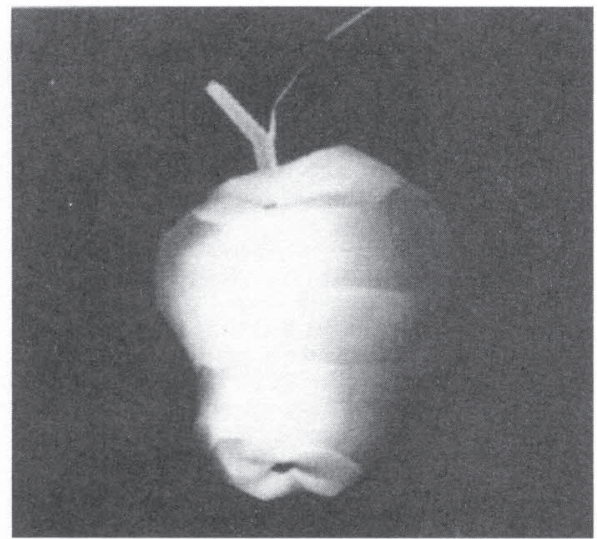

1. ábra

Alma

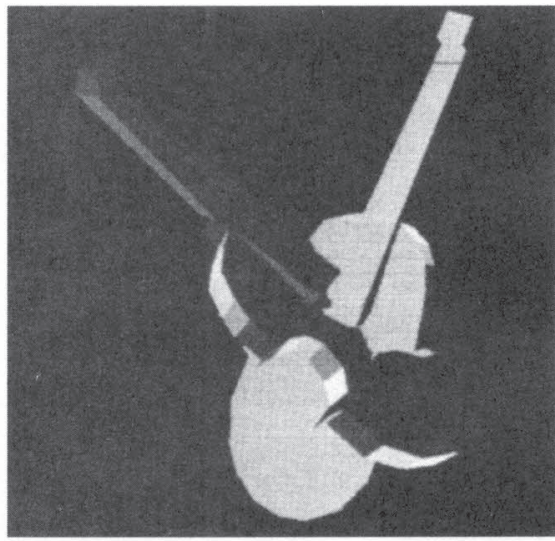

2. ábra

Két hegedü metszete

Az „alma” és a „hegedúk” képe (ez utóbbi két hangszer virtuális metszete) egy konkáv poliédereket leképezó háromdimenziós megjelenítő algoritmus felhasználását illusztrálja.

A múvészek folyamatosan átértékelik a környezetükból érkező információkat, új módokat keresve a világról alkotott személyes felfogásuk és a világhoz fúzốdố kapcsolataik kifejezésére. Azt is mondhatnánk, hogy ezeket a „valós adatokat” a múvészek - bizonyos transzformációkat hajtva végre rajtuk - bizonyos valóságszemlélet kifejezésére használják.

${ }^{1}$ http://www.atariarchives.org/artist/sec25.php 
A múvészi kifejezéshez felhasználható adatok körébe tartoznak a külső világ numerikus vagy statisztikai reprezentációi is. Tömegtársadalomban élvén, állandóan méregetjük és értékeljük önmagunkat, hogy megértsük saját problémáinkat és szükségleteinket. Folyamatosan frissített statisztikai kimutatásokat készítünk a munkanélküliségról, a búnözésról, a közúti balesetekról, a válásokról, az elmebetegségekról, a születésekról és az elhalálozásokról, az alkoholistákról, a zöld területek arányáról, a környezetszennyezésról, a várható élettartamról... és még igen sok mindenról.

A komplex társadalmi problémákat szükségképpen meg kell értenünk ahhoz, hogy meg tudjuk oldani óket. A számítástechnikai eszközök megjelenésével képessé váltunk igen nagy adatbázisok és azokat kezelő programok létrehozására, amelyek a statisztikai információk tömegeit bocsátják ki. Ez a képességünk fenomenálisnak mondható, az adatok értelmezésével azonban általában nehezen boldogulunk. Az adatok ugyanis rendkívül összetettek lehetnek, különösen akkor, ha trendekkel, többváltozós kapcsolatokkal, az adatok szóródásával és különféle változásaival van dolgunk. Sok társadalomtudós csupán az efféle adatok numerikus megjelenítésére szorítkozik, abban a hitben, hogy ez a semlegesség vagy az objektív megítélés pozícióját ígéri számára. Biderman² és a kutatók egy viszonylag kicsiny csoportja szerint ugyanakkor döntô fontosságú az ilyen jellegú információk közzétételi és értelmezési lehetôségeinek a fejlesztése. A tökéletesített vizuális megjelenítési technikák sokat segíthetnek racionálisabb döntések meghozatalában arra nézve, hogy az eróforrásokat hogyan használjuk fel, és hogyan oldjuk meg a társadalmi problémákat.

A statisztika nemcsak kvantitatív méréseket, hanem afféle valóságszemléletet is jelent. A múvészek ma - ahelyett, hogy a valóság vizuális formáira vagy külső megjelenésére figyelnének - közvetlenül a tartalommal foglalkozhatnak. Új konceptuális tájkép bontakozik ki, a maga hegyeivel, völgyeivel és síkságaival, sokféle textúrával és a színek fokozatos átmeneteivel a sötét és a világos tónusok között. A számítógépek segítségével a múvész a társadalom valamennyi aspektusára vonatkozó valós adatok reprezentációiként kezelheti a statisztikai kimutatásokat, beleértve a tragikus, komikus, sốt akár szürrealisztikus nézốpontokból észlelt problémák megjelenítését. Így a múvésznek lehetôsége nyílik új módon kifejezni a valóságról alkotott felfogását.

Az interaktív számítógépes grafika módot ad arra, hogy közvetlen kölcsönhatásba lépjünk az információkkal, sokatmondóvá téve az adatok numerikus reprezentációit. A felhasználó interaktív módon alkalmazhat különféle matematikai modelleket, amelyek szimulálni tudnak társadalmi rendszereket vagy absztrakt folyamatokat, sốt esztétikai tárgyakat is. A számítógépes animáció és grafika révén a felhasználó dinamikus képi eszközök birtokába jut a saját beavatkozása folytán bekövetkezó változási folyamatok követéséhez, s ez lehetôvé teszi azoknak a komplex kapcsolatoknak a jobb megértését, amelyek meghatározzák a beavatkozás eredményét.

A szoftverek funkcióinak köszönhetôen a felhasználó különféle interaktív beavatkozásokkal módosíthatja a rendszer paramétereit, bonyolult görbületeket rajzolhat újra anélkül, hogy egyáltalán gondolnia kellene a számadatokra. A szimulációs modell ugyanezt hajtja végre, viszont kevesebb elôzetes ismeretet vár el a felhasználótól, és így tulajdonképpen többet ad.

2 Albert D. Biderman: Kinostatistics for Social Indicators. Washington D. C., 1971, Bureau of Social Research Report (a szerzö eredeti lábjegyzete). 
Az ember és a gép közötti kommunikáció megvalósítására kidolgozott technikai megoldások közül számos eljárás alkalmazható a számítógépes múvészetben és az esztétikai indíttatású szimulációkban. A számítógépes múvészetet a legtöbb ember hajlamos azonosítani a statikus grafikai múvekkel vagy az animációs filmekkel. A számítógéppel valamilyen interfész útján - például fényre, hangra vagy hốre reagáló szenzorok segítségével - összekapcsolt fizikai múalkotások esetében azonban módosulás következik be a mú valamelyik összetevőjében, a kapcsolatok új halmazát hozva létre. A számítógép közremúködésével előállított múalkotást olyan valós idóben létezô objektumnak is tekinthetjük, amely módot ad a felhasználó (a közönség) részvételére és irányító jellegú szerepvállalására a mú megalkotásában. A valós idóben létező számítógépes múalkotás olyan intellektuális koncepció, amely nem valamilyen végleges formát öltött anyagi tárgyban, hanem vizuális tapasztalatokban manifesztálódik. Az ilyenfajta számítógépes múalkotás csupán arra az idôre létezik, amíg a létrehozásában részt vevő közönség és a képernyővel összekapcsolt számítógép egy adott folyamatban kölcsönhatásba lép egymással. A múalkotás nem a számítógép, és nem is az, ami a képernyốn megjelenik, hanem mindkettőnek a nézốvel való interakciója. Ennek a múvészi kifejezési formának a tartalma - múvészi paraméterein túl - függ annak a valós idejú folyamatnak a dinamikájától, amely életre hívja az animáció vagy a nézóvel megvalósuló interakció vizuális megjelenítését. Az ilyen múalkotások egy másik fontos vonása az alternatív választási lehetôségek vizsgálatát lehetôvé tevố azonnali vizuális visszacsatolás. Minden résztvevőnek alkalma nyílik az esztétikumot hordozó mútárgy „megtapasztalására” valamilyen sajátos szinten, ami háttérismereteitôl és képzettségétól függ.

A valós idejú számítógépes múalkotások előállítására alkalmas rendszerek úgy vannak felépítve, hogy a nézố a részvétele útján jut hozzá az esztétikai élményhez. A passzív „nézốnek” aktív „,résztvevớvé” kell válnia a rendszer által nyújtott konkrét környezetben. Megalapozottan állíthatjuk, hogy a múvészet képes alakítani a felfogóképességünket, és mivel a mú befogadása nem a látvány valamiféle passzív elraktározása, hanem aktív pszichés szervezốdési folyamat, a múalkotás csupán a hozzá kapcsolódó aktív részvételi tevékenység útján fogható fel, és ily módon - éppen a befogadása révén - megváltoztatja a „valóság” struktúráját a tudatunkban.

A valós világ tárgyait és jelenségeit szimuláló „valós idejư” mưalkotás a gyakorlatban többnyire olyan interaktív rendszerként jelenik meg, amely animációs vagy grafikai prezentációból és egy statisztikai algoritmusból épül fel. Az algoritmust beépítik egy számítógépes programba, és háttér-információként általános magyarázatot csatolnak hozzá.

Az AID (Automatic Interaction Detector) elnevezésú kölcsönhatás-feltáró programot eredetileg 1963-ban dolgozták ki a Michigani Egyetemen. Ez a program potenciálisan felhasználható bármilyen elemzésre, melynek során a vizsgált változó értékeinek alakulását független vagy prediktív változók kombinációjával próbáljuk megmagyarázni. A program eltér a konvencionális többszörös regressziós technikáktól: nem feltételezi, hogy a modell lineáris és a prediktív változói viszonylag szabad értékkészletet vesznek fel anélkül, hogy érvénytelenné tennék az elemzést.

Az AID-technika segítségével akár 140 prediktor összefüggései is megvizsgálhatók. A változók egyikét függố változónak választjuk. A technika ismételten két csoport- 
ra választja szét az adatokat, hogy minimalizálja a függő változó varianciáját. A program kimenete lényegében egy fastruktúra, amely összefoglalja a végrehajtott szétválasztási folyamatot. Az eredményként kapott fa szimmetriája vagy aszimmetriája a prediktorok kölcsönhatásait tükrözi. A fa könnyedén ábrázolható egy képernyoón. A fa feltérképezését a felhasználó megállási feltételek beiktatásával szakíthatja meg. Az AID-technika alkalmazásának eredményeit rendszerint fadiagramok formájában közlik: egy-egy fán minden egyes csomópont a prediktorváltozók értékeinek egy adott kombinációja mellett tett megfigyelések halmazát jeleníti meg. A fastruktúra csúcspontjai általában tartalmazzák a függố változó átlagértékét és standard szórását, valamint a megfigyelések számát és a megfelelố prediktorok értékeit.

Egy interaktív grafikus szimuláció lefuttatása az AID-programmal a következőképpen írható le: A résztvevő́ vagy felhasználó egy számítógéppel összekapcsolt képernyố elốtt ül, az interakciót számos eszköz - köztük számlapok, funkcióbillentyúk, fényceruza, botkormány, 3D hangceruza és billentyúzet - teszi lehetôvé. A ténylegesen végrehajtott kísérlethez PDP-11/45 típusú számítógépet és Vector General grafikus képernyốt használtunk.

A grafikai szimulációs modell múk ödése egy AID-fa felrajzolásával kezdődik, miközben a felhasználó figyeli a változók közötti kapcsolatokat, ahogyan a fa kirajzolódik. Az AID-program használatakor a fa növekedésében valamiféle rend nyilvánul meg. Alsóbb ágai törölhetók, ha a felhasználó meg kívánja fordítani a folyamatot. A számítógépben úgy tárolódik a valós adatok történetének (múltjának és elốrevetített jövôjének) szimulációja, ahogyan a mozzanatokat rögzítố képek egy animációs szekvenciában. Lineáris interpolációs technikával az idóben folyamatos és finom mozgás érhetó el. A botkormány lehetốvé teszi az idố szabályozását: eloóretolásával a felhasználó elốre halad az idóben, hátrahúzásával pedig megfordul az idô. A képernyố alsó részében egy óra foglal helyet, fent egy kétdimenziós skála helyezkedik el, középen pedig egy AIDstruktúra látható. Ahogy a felhasználó mozgatja a botkormányt (az óra elmozdul például 1024-ról 2048-ra), ez a struktúra megváltoztatja a helyzetét és az alakját, s mindez dinamikusan, folytonosan megy végbe. A funkcióbillentyúk lenyomásával a felhasználó kiválaszthat egy-egy változót, és a botkormány mozgatásával azt eloore vagy hátra elmozdíthatja az idóben. Ugyanez az eljárás alkalmazható mind a vonalas, mind a tónusos képek esetében. A grafika képes dinamikusan megmutatni egy kritikus ösvény kirajzolódását, azzal jelezve az adatok között a legfontosabb változó felé vezető utat, hogy az útvonal felépülése során a vonalak kifényesednek.

Ez a modell az adatok háromdimenziós megjelenítésére is alkalmas. A fastruktúrák rétegesen, egymás fölött helyezkednek el a $Z$ tengely mentén: az egységkockán belül mindegyik bejegyzés egy időintervallumot (5-10 évet) jelöl. Az időszeleteket összekötő vonalak egy felületet hoznak létre. Az egységkocka elülsó lapja a jelen idônek felel meg, ami pedig mögötte van, az a múltat jelöli. A felhasználó forgathatja a háromdimenziós modellt, és a botkormánnyal az idôben való elmozdulást is szimulálhatja. Az egyes rétegek vastagsága tetszóleges tényezóket szimbolizálhat. A struktúra olyan szögben is elforgatható, hogy láthatóvá váljon a felülnézet. Ez hagyományosabb módon, a megszokott koordináta-rendszerben ábrázolja az adatokat: az egyik tengelyen az idôskála, egy másik tengely mentén pedig az eloszlás, a százalékos adatok jelennek meg. 


\section{3. ábra}

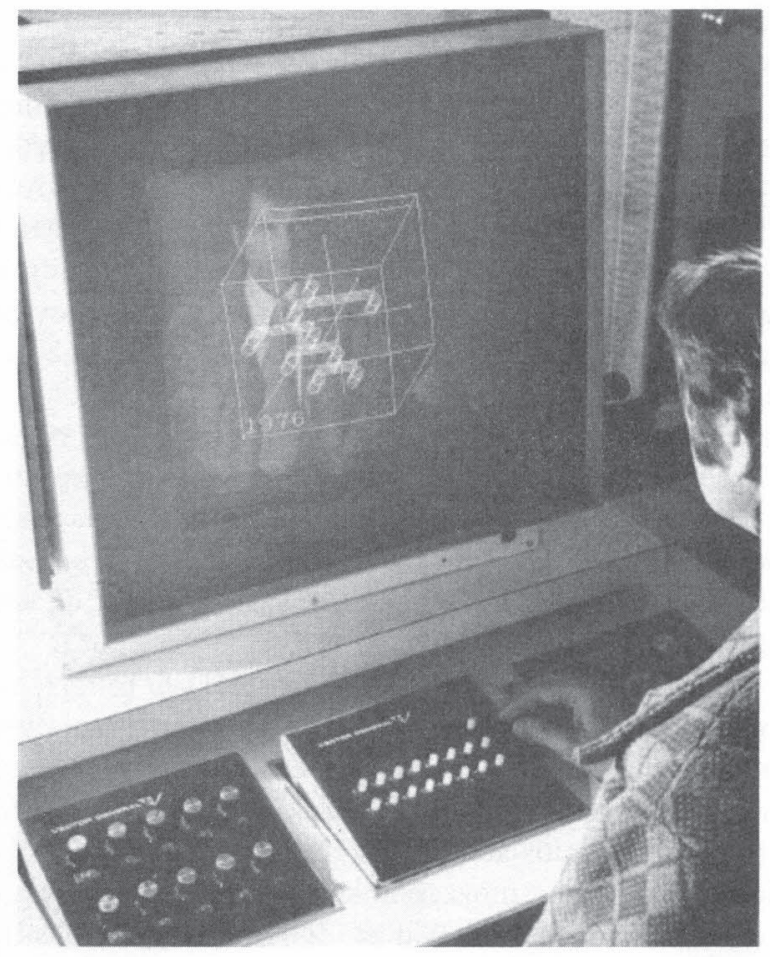

Képernyố és kezelöszervek

Az AID-programot egy fastruktúra reprezentálja, egyes algoritmusok azonban a molekuláris szerkezet modelljét is használhatják. A molekulaszerkezet egyes részeinek mérete és színe a releváns adatkapcsolatok erốsségének a függvényében változik. A több objektummal, illetve felülettel dolgozó kinetikus modellek megjelenítésére különböző geometriai formák használhatók fel. Ezeket interaktív módon lehet mozgatni a háromdimenziós térben, miközben a mozgás sebességétól függóen változtathatják a színüket, alakjukat és méretüket - az adatok közötti kapcsolatokat jelezve. Egyes tárgyakat úgy is meg lehet jeleníteni, mintha valamilyen elasztikus anyagból állnának. Az efféle paraméterek funkcióbillentyúk lenyomásával kapcsolhatók be. Ha a felhasználó sztereó szemüveget és 3D hangceruzát használ, a ceruzával mintegy „,megérintheti” az elasztikus tárgyat, mire az dinamikusan megváltoztatja az alakját. Az alakváltozás minősége a rendszer változóinak értékétól függ: az adatokat maguk a formák hordozzák.

Az Ohiói Állami Egyetemen múködő Számítógépes Grafikai Kutatócsoport tagjai egyebek között azt a célt tûzték maguk elé, hogy kutatási eszközként használható, színes videoképernyoón történó grafikus megjelenítésre alkalmas szoftvert fejlesszenek ki. Az általuk létrehozott hardver- és szoftverrendszer összekapcsolható kétirányú kábeltelevízióval is. Ily módon távoli tévékészülékeknél és termináloknál elhelyezkedô közönség is részt vehet egy statisztikai múalkotás élvezetében.

A statisztikai adatok vizuális megjelenítésére irányuló eredeti szándék a társadalmi problémák feltárásának és elemzésének az elósegítése volt, az effajta „kinostatisztika” 
potenciálisan igen fontos anyagot nyújthat a múvészi kifejezés számára is. A múvészek jelentős szerepet játszhatnak az ilyen irányú kutatások társadalomtudományi aspektusainak feltárásában, de a valós világból származó adatok világát megközelíthetik tisztán múvészi nézópontból is, a valóságról alkotott felfogásuk kifejezésére törekedve. ${ }^{3}$

\section{Charles Csuri: A képzelet barangolásai (1993)}

Amikor azon töprengek, hogy vajon hogyan befolyásolják a gondolkodásomat, különösen a valóságfelfogásomat a mítoszok, maga a mitológia siet a segítségemre. A mítoszok ơseink gazdag képzeletvilágának örökségét hordozzák, amely még ma is alakítja szemléletünket, ahogyan a természetet, a világ történetét és eljövendő sorsát, az isteneket, az embert és a társadalmat látjuk. Hajlok arra, hogy a mítoszokat inkább költészetnek tekintsem, és ne vegyem óket szó szerint sem történeti, sem tudományos értelemben. A mitológiában - mintegy a világ szimbolikus leképezéseként - bizonyos költói kifejezésmód testesül meg számomra, amely megvilágítja a dolgok értelmét a felszín alatt.

Érdekelnek a különböző kultúrák mítoszai között mutatkozó hasonlóságok és párhuzamok, azok a minták, amelyek magyarázatokat kínálnak az élet eredetére és a mindannyiunk világszemléletét befolyásoló erók múködésére. A mítoszok sok tekintetben a valóság lényegi kivonatai, amelyek befészkelik magukat a tudatunkba, és alakítják létfelfogásunkat. Az emberi lények mindig is teremtettek ilyen virtuális valóságokat, hogy életüknek értelmet és célt adjanak.

A jelenségek - például a mennydörgés-villámlás vagy a hurrikánok - tudományos magyarázatánál számomra kedvesebbek az istenek, a Mennydörgő Villámok Istene vagy a Szelek Istene, akik megmozgatják a múvészi képzelőerőmet. Kedves számomra az a gondolat, hogy az ember agyagból formálódott ki egy fazekaskorongon, vagy egy kozmikus tojásból bukkant eló.

Az egyiptomiak egyik istene, Knum azt súgta nekem, hogy ő hozta létre az egész emberi fajt a fazekaskorongján. Azt tanácsolta, hogy ne nagyon bízzam a tudományos elméletekben, mivel azok nem igazán adnak értelmes magyarázatot az univerzum eredetére vagy az emberiség megjelenésére itt a Földön. Számomra elborzasztó még csak elgondolni is, hogy valaha semmi sem volt, csak sötétség, és csak azután jelent meg a fény. De vajon mikor? Lehetséges, hogy az anyag a fényból és a tér a vízból keletkezett?

Sok isten van, akik befolyásoltak a munkámban, és útmutatást adtak nekem a valóság megjelenítéséhez. A hindu isten, Prajapati és Brahma, a teremtmények ura, az univerzum megalkotója, az istenek, az álmok és minden élólények atyja arra biztatott, hogy álomszerú valóságot teremtsek, ahol különös, torz figurák, szörnyek és mindenféle hibrid lények élnek, akik változtatják az alakjukat, és mágikus erejük van.

${ }^{3}$ A szerző köszönetnyilvánítását, amelyet esszéjéhe» csatolt, lábjegyzetben közöljük: „Öszintén hálás vagyok a Számítógépes Grafikai Kutatócsoportnak (Computer Graphics Research Group, CGRG) a szoftver és a hardver kidolgozásáért, ami lehetôvé tette ezt a kísérletet. Az interaktív AID szimulációs modell programozását Ronald Hackathorn és Allan Myers végezte. Az AID-programot George Tressel ajánlotta figyelmembe: megjegyzéseit és javaslatait igen nagyra értékelem. A CGRG számára a tudományos kutatási eszközként felhasználható valós idejú animációs és grafikai technikák kifejlesztésćhcz a National Science Foundation biztosította a szükséges támogatást, a DCR 74-00768A01 számú projekt keretében."

${ }^{4}$ Ramblings of a feverish mind. http://www.csurivision.com/charles-csuri/digital-art-0_0.php 
A japán Amida Buddha (a Végtelen Fény) arra tanított, hogyan használjam fel a színeket, amelyeket itt, a mi világunkban nem köt gúzsba a létezố tárgyak geometriája, és úgy múködnek, mint a fény a határtalan háromdimenziós térben. Azt mondta, hogy a valóság megjelenítéséhez szükségem van a végtelenség aurájára.

Egy másik hindu isten, Varuna szintén beszélt nekem a mindent átöleló és megvilágító végtelenség spirituális képéról. Nem vagyok biztos benne, hogy jól értem, mit ért ezen, de arra ösztönzött, hogy fénybe burkolt valóságot próbáljak teremteni. Azt ajánlotta, hogy elmélkedjem a nemlétból kiemelkedő úr éteri tisztaságáról.

Uranosz, az ég görög istene meghívott, hogy hagyjam el a Földet, és éljek az ô birodalmában. Az ég egyiptomi istennóje, Nut szintén azt mondta nekem, hogy ne törôdjek a gravitációval, és felejtsem el, hogy fizikai valónkban sík felületen élünk. Az árnyékok semmit sem mondanak, egyszerúen csak a Földhöz kötnek bennünket, és amellett az alvilág gonosz szellemeit képviselik. Azt a jó tanácsot kaptam tólük, hogy mindenáron kerüljem el Perszephonét, az alvilág görög királynőjét, és Oziriszt, a halál egyiptomi istenét.

Az ég, a szabad levegó nyílt távlatai illenek ahhoz, amit múvészként el akarok mondani. A görög Psziché arra tanított, hogy a képeimben próbáljam kifejezésre juttatni a mítoszok kollektív tudatalattiját, amely beleszövődött a lelkembe. Knum, a teremtố isten biztatott, hogy bátran kísérletezzek, és ne törekedjek következetes múvészi stílusra, mert a mondanivalóm el fog jutni a közönséghez, függetlenül a stílustól. Nem szabad bátortalannak lennem sem a technika, sem az újítások tekintetében: arra kell törekednem, hogy csakis a valósággal kapcsolatos érzéseimet tolmácsoljam. Amikor megkérdeztem tóle, hogy vajon egyszer majd gazdag és híres leszek-e, Knum hangosan felkacagott. Ugyanakkor hallottam a háttérból más istenek, Amida, Varuna, Nut és Psziché nevetését is. Azután mindannyian kórusban kezdték kántálni: „Csak a valóságot... a valóságot... a valóságot!"

Ott van azután még az elképzelhetetlen skandináv isten, Odin, a varázslók istene, akinek hatalmában áll megváltoztatni a külsejét, és bármilyen álcázott alakban meg tud jelenni. Ố elmagyarázta nekem, hogyan mutathatom meg a valóság természetét, amelyhez a rend és a káosz is hozzátartozik, bármennyire szemben állnak egymással. Azt is tanácsolta, hogy az életemben és a munkámban egyaránt merészkedjem el egészen a kaotikus rendszerek határáig, mert így hajlékonyabban, rugalmasabban láthatom és láttathatom a világot, mint akkor, ha megmaradok a rendezett lineáris rendszerek tartományában. Ma csakugyan biztosabban irányítom a dolgok alakulását, amikor gyengéd noszogatásomra a káoszból múvészi alkotás bukkan elő.

Odin isten szerint a képeimben lehet néha egy-egy világosan látható objektum is, és ezek mellett jól megférhetnek az idố és a valóság visszhangját hordozó másodlagos, félig áttetszó formációk. Azt mondta nekem, hogy feltétlenül illesszem be a múveimbe a határtalan térben lebegô dolgok reprezentációit. (Még az egek amerikai indián istene is arra buzdított, hogy ezeket a fragmentumokat valami olyan mágikus erejú ósanyag darabkáinak tekintsem, amit azért permeteztek az ûrbe, hogy emberek és tárgyak szülessenek belóle.)

Odin arra is tanított, hogyan mutassam meg - egyidejúleg több nézópontból - a dolgok utánzatait is, de ebból csak ellentmondások születtek. Éreztem, hogy Odin a segítségemre lehet, tehát meglehetốsen sok idốt töltöttem vele. Hiába próbáltam azon- 
ban beszélni neki arról, hogy nagyon szeretném hangsúlyosan megjeleníteni a háromdimenziós teret a munkáimban. Csak késóbb értettem meg a közömbösségét, amikor felfedeztem, hogy csak egyetlen szeme van - a másikat, ha jól tudom, egy ôrültséggel határos vállalkozása során veszítette el. Odin, aki egyszersmind a bölcsesség istene is, világosan megmondta nekem, hogy a múvészet területén nincs semmi új, csupán különbözó külsố megjelenési formák hordozzák mindig ugyanazokat az eszméket az emberi lényekról és létezésükról a világban.

Pán, a gonoszkodás görög istene a számítógépemben lakik. Az én törekvéseim, hogy a számítógép képességeit a múvészi alkotással kapcsolatos új elgondolások valóra váltására fordítsam, nagyon bosszantják Pánt, aki mindig nagy örömét leli abban, ha meggyötörhet, és különféle hibákkal folyton zavarba hoz, hogy kétszer is meggondoljam, mit múvelek a számítógéppel.

Érdekes kapcsolatban állunk: ő szándékosan eltorzítja a paramétereimet, és olyan képekkel lep meg, amelyeket elrettentớnek vél. Legtöbbször ez így is van, de idốnként hibát követ el, s ennek köszönhetốen olyan meghökkentố képeket sikerül produkálnom, amelyeket sohasem láthattam volna előre, és azután ezeket a képeket is a saját személyes alkotásomnak kiálthatom ki.

Amikor ez történik, ô dühbe gurul, és lefagyasztja a számítógépemet: ilyenkor az ördögi oldala bújik elô. Késóbb azután megengesztelődik, mert valójában élvezi ezt a játékot velem, tudván, hogy legtöbbször ő nyer. Be kell vallanom, magam is nagyon szeretem Pán játékos attitúdjét a múvészet és a számítógépek iránt.

\section{Charles Csuri: Virtuális objektumok szanatóriuma ${ }^{5}$ (1994)}

A napjaim általában úgy kezdôdnek, hogy megreggelizem egy közeli étteremben, majd autóval bemegyek az egyetemre. Belépek a szobámba, és leülök a számítógéphez abban a reményben, hogy a rendszer nem omlott össze az éjszaka folyamán, és elkezdhetek dolgozni. Ma is megpróbáltam bekapcsolni a gépet, de a bejelentkezéskor elkövettem egy hibát.

Elôször rosszul gépeltem be a nevemet, mivel a „Csuri” név betúkombinációja kissé szokatlan. Ez megtörténik néha, annak ellenére, hogy a saját nevemról van szó. Ma valószínúleg fáradt voltam, vagy egyszerúen nem ittam meg egy negyedik csésze kávét is. A rendszer ilyenkor is megköveteli, hogy az ember - még egy új név bevitele elótt - beírjon egy jelszót is. A következô próbálkozáskor a nevemet már helyesen pötyögtem be, de azután elírtam a jelszót. Végül csak egy-két újabb nekifutás után tudtam bejelentkezni a számítógépembe.

A problémák felmerülése a nevem és a jelszavam beírásakor bizonyára figyelmeztetô, baljós jel volt arra nézve, ami ezután következett. Valójában azonban csak akkor váltam nyugtalanná, amikor a monitoron megjelent egy koponya kisméretú ikonja. Rákattintottam az egérrel, és íme, elôtúnt a „Virtuális objektumok szanatóriuma”.

\footnotetext{
${ }^{5}$ Mental Institution For Digital Art Objects. http://www.csurivision.com/charles-csuri/digital-art-2_0. php
} 
Hát ez meg mi az ördög? - gondoltam magamban. Nem emlékeztem rá, hogy ilyen jelzésû adatállományt létrehoztam volna. Talán valakinek a quick time videofelvétele lehet? Itt volt elóttem egy színes, valós idejư grafikus megjelenítési rendszer. Egyszerúen nem hittem a szememnek, és egy pillanatig arra gondoltam, hogy ez valami különös szürrealista álom. (Eszembe jutott, hogy valamikor beszereztem egy ultranagy sebességú grafikus processzort a számítógépemhez, és valahol az egyik meghajtómon megvan a kód is egy ilyen rendszer múködtetéséhez.)

Azon kaptam magam, hogy egy háromdimenziós környezetet bámulok, amelyben minden objektum nagy felbontással, élénk színekkel jelenik meg, saját hanggal, megfelelő megvilágítással és plasztikus árnyékokkal, és ráadásul mindannyian egymástól függetlenül, különféle sebességgel mozognak, bizonyos helyeken eltúnnek, majd újra elóbukkannak. Világosan látható volt, hogy egy különleges közösségbe léptem be, amely szinte pezsgett az élettól, az energiától és a tevékenységtól.

Mindenféle absztrakt 3D-s forma feltưnt a képernyoón, köztük egyszerú kockák, gömbök, sốt figurális reprezentációk is. Az objektumok nagy száma miatt vizuálisan nehezen volt áttekinthető az egész, és kezdetben a zajszint igen magas volt. Az objektumok valahogyan megtanultak beszélni, és úgy társalogtak, mint az emberi lények.

Késóbb megtudtam tólük, hogy mindezt az interneten keresztül tanulták egy tízéves számítógépbolond kölyöktól, aki Új-Zélandon él. Ez az ifjú zseni nem csupán valóban komplex eljárásokat dolgozott ki, amelyek mindezt lehetôvé tették. Úgy tû́nt, hogy felhasználta a kognitív tudomány, a biológia, a fizika, a genetika és a mesterséges intelligencia területéról származó eredményeket is.

Megértettem, hogy ez a teljesítmény valóságos szökőárt indíthat el, amely végigsöpör a számítástechnika egész birodalmán, és azzal fenyeget, hogy egy csapásra elavulttá teszi mindazt, amit tudunk. Azt üzeni, hogy a számítógéptudósok és a programozók szerepe hamarosan olyan lesz, mint az autószerelóké.

Az objektumok a képernyőmön anyagszerűek és sokszínúek voltak: virágok, emberek és állatok reprezentációi is megjelentek köztük. Gyönyörúnek, elbúvölőnek és egyszersmind titokzatosnak túntek, különösen akkor, amikor felismertem, hogy a saját képeimból származnak (természetesen már csak ezért is egészen speciálisnak kellett lenniük). Hamarosan felfigyeltek a jelenlétemre, odajöttek hozzám, és a legnagyobb örömömre beszélni kezdtek hozzám.

Megkérdeztem tólük, hogy honnan bukkantak elő, és ugyan miért nevezték el a saját közösségüket az „objektumok szanatóriumának”. Azt felelték, hogy amikor én befejeztem és nyomtatható formában rögzítettem egy-egy képet, nem maradt többé semmi tennivalójuk. Talonba tettem óket, s ennek következtében a mellózöttség és a kizsákmányoltság érzése lett úrrá rajtuk, nagyon magányosnak érezték magukat, és mélyen elkeseredtek. Múködésképtelenné váltak, és nem tudtak megbirkózni az adott állományon kívüli valósággal.

Azt mondták, hogy olyan érzéseik vannak, mint az emberi lényeknek: nem mechanikus figurák, hanem lelki életet élnek. Ahhoz, hogy életben maradhassanak, létre kellett hozniuk a saját közösségüket, ahol megoszthatják egymással a gondolataikat és érzéseiket. Reményre volt szükségük, hogy egyszer majd valaki vagy valami a segítségükre siet, hogy átköltözhessenek egy másik világba, ahol jobb életük lehet. 
Kezdetben annyira le voltam nyúgözve, hogy nem tudtam mit válaszolni a gondjaikra, s így csak folytattam a viselkedésük megfigyelését. Több kocka élénk párbeszédet folytatott a végtelenrôl. Egyikük, aki nőnemúnek bizonyult, azt mondta, hogy mindig különös álmaik voltak a végtelenról, homályos elképzelésekkel az időról és a távolságokról. Elpanaszolta, hogy amikor én beállítom a paramétereket a számítógép programjában, soha sem engedem meg neki, hogy továbblépjen az egyes számnál. Nyilvánvalóan túlságosan konzervatív vagyok, és ók sohasem pillanthatják meg a végtelent, hacsak nem lesz elég bátorságom valamikor túllépni az egyes számon.

Azután észrevettem egy gömböt, amelyik folyton csuklott, és ilyenkor hirtelen ellipszoiddá változott az alakja, majd ismét visszaalakult gömbbé. Rájöttem, hogy a skála egyik paraméterét helytelenül állítottam be, és ennek következtében neki az a nyomorúságos sors jutott, hogy egész életében ez a betegség kínozza. A szerencsétlen egyre csak könyörgött nekem, hogy hajtsam végre a szükséges korrekciót, amitól normális életet élhetne.

Volt továbbá egy kocka, amely a térben ide-oda mozgott, és egész idô alatt folyton vihogott. Egyszerúen muszáj volt folytatnia ezt a buta vihogást - akárcsak egy nagyon fiatal gyerek, akinek valami titka van, amit magának akar megtartani. Sohasem jöttem rá, hogy miért csuklott. Egy másik kocka beszélt valamikor az egyik számítógép-tudomány szakos diákunkkal, és az megtanította arra, hogyan lehet olyan csontvázat kialakítani, amelynek az ízületei mindig a kocka terén belül maradnak. Ez a kocka igen rugalmassá vált: képes volt elhajlítani, megcsavarni és úgy mozgatni ide-oda a csúcspontjait, mintha karok és lábak volnának. Igen izgatott volt, körbe-körbe járt, megölelgette a többieket, és mindenkinek azt mondogatta: „Szeretlek, szeretlek.”

Megtudtam, hogy mindegyik objektum ízületekkel illeszkedő, belső csontvázszerkezetre tesz szert. Volt köztük egy absztrakt struktúra, amely teljesen összezavarta az irányokat. Ha azt mondta neki az ember, hogy mozduljon el jobbra, akkor balra vagy fölfelé, vagy akár lefelé indult meg. Ha arra kérték, hogy forogjon az óramutató járásával megegyező irányban a z tengely körül, az ellenkező irányban kezdett forogni. Erre is jól emlékeztem, mert olyan sok bajt okozott nekem annak idején, amikor órákig próbálkoztam egyszerú döntések bevitelével a programba. Az egyik objektum folyamatosan járkált körbe-körbe, és ezt mormogta maga elé: „Idő vagyok, nem tér vagyok, idő vagyok, nem tér vagyok."

Valóban rejtélyes és bizarr az az énkép, amelyet az objektumok önmagukról kialakítottak. Nem tudom, hogyan csinálták, de egyesek közülük kitúnő szaglóérzéket fejlesztettek ki. Jártukban-keltükben odamondogattak a társaiknak, hogy azok úgy búzlenek már messziról, mint a szemét. Nem szívesen beszélek arról, aki állandóan maga alá piszkított. Az összes többi objektum panaszkodott rá, és csakugyan nagyon összerondította a környezetét.

Végül volt közöttük egy, aki állandóan siránkozott, és ezt óbégatta: „Elavultam, elavultam.” Valóban súlyos múködési rendellenességgel küzdött: látszott rajta, hogy nagy szüksége volna komoly pszichiátriai kezelésre.

Miközben ez a zsibvásár folytatódott a képernyốn, észrevettem egy nagyobb csoportot a háttérben, amely igen izgatottnak túnt: mindenki föl-le ugrált benne. Odajöttek hozzám, és elkezdtek siránkozni, majd dühösen kiabálva árulónak és gyávának neveztek. Egy pillanatig azt hittem, hogy meg akarnak támadni, és nagyon megrémültem. 
Azt mondták, hogy amikor beállítom a képi környezetet, folyton egy új rendszerról beszélek, ahol az objektumok kommunikálni tudnak majd egymással. Megígértem nekik, hogy nagyobb szerepet fognak kapni a múvészi munkámban. Olyan szavakat használtam, mint például „intelligens” vagy „kognitív” objektum, és „perceptív pixelekról" beszéltem. Mindig valami magasabb szintú irányítást emlegettem, melynek révén szabályokat állíthatok fel arra nézve, hogy ók miként kommunikálhatnak, és hogyan múködhetnek együtt egymással a térben. Azt mondtam, hogy adok számukra némi szabadságot, bizonyos intervallumokat jelölve ki a paraméterek értékeihez, és azután ók hozhatják meg a döntéseket. Valójában azonban egyszerúen nem adtam esélyt számukra, hogy segítsenek nekem. Az objektumok most újra a tudtomra adták, hogy komolyabb szerepet akarnak játszani ennek az újfajta múvészetnek a megteremtésében.

Erôsen átfútött beszélgetést folytattunk mindezekról a kérdésekról és problémákról. Végül eljutottunk egy olyan szintre, ahol elhatároztuk, hogy közös javaslatot dolgozunk ki. Nekem tetszettek az ötleteik, a meglátásaik helyesek voltak a szoftverek ilyen irányban történố további fejlesztését illetốen, tehát beláttam, hogy érdemes rájuk támaszkodnom. Mivel képesek voltak üzenetek váltására, miért ne használnám ki ezt az új lehetôséget a múveim létrehozásakor?

Többen közülük arról tájékoztattak, hogy képesek kapcsolatba lépni Nostradamusszal, a reneszánsz filozófussal, aki meg tudta jósolni a jövớt. Órákat vettek tóle, és most már ốk is képesek a jövő elôrelátására. Ennek természetesen nem tudtam ellenállni, és megkérdeztem tốlük, hogy múvészként mi lesz a sorsom.

Azt mondták, hogy egyre rosszabb múvész leszek, fóleg azért, mert hagyom, hogy megrontsanak a speciális effektusokat produkáló szoftverek. Össze fogom téveszteni a speciális effektusokat a múvészettel, s ugyanakkor megfeledkezem a múvészet történetéról, és az olyan emberekról, mint Botticelli, Raffaello, Rembrandt, Cézanne stb. Múvészként nem lesz osztályrészem a hírnév és a gazdagság, feledésbe fogok merülni. Ez a jóslat komoly csapás volt az egómra nézve, és természetesen nagyon-nagyon csalódott voltam: mélyen megbántottnak éreztem magam, amikor mindezt hallottam tólük.

Mindazonáltal azt is elmondták, hogy kétszázmillió év múlva a régészek fel fogják fedezni azt a számítógéppel alkotott szobrot, amelyet 1967-ben csináltam. Az én számítógéppel generált szobrom - mi az ördög akart ez lenni, méghozzá kétszázmillió évvel ezután?? Úgy tứnt, hogy valamilyen katasztrófa fog bekövetkezni, és a legtöbb társadalom elpusztul technológiai eredményeinkkel együtt. Lesz azonban valamilyen újjászületés is, és az emberiség újból keresztül fog menni a fejlődésnek ugyanazon a fokozatain, mint a jelenlegi kultúránk.

A régészek hosszasan vitatkozni fognak arról, hogy az én szobromnak hol van a helye a bolygó korai történetében, és vajon hogyan készült. A szerszámok által a szobor felületén hagyott nyomokat sokféleképpen fogják értelmezni. Ekkorra a régészek már nevet is adtak valamikor a szobromnak, de a késóbbi kutatók nem emlékeztek rá pontosan, hogy mi is volt az: talán valami olyasmi, hogy „korai erdei ember” vagy „korai együgyú ember".

Nos, ennyit a jövớról: Nostradamus talán rossz tanár volt. Végül megmondtam az objektumoknak, hogy megrendültem a saját érzéketlenségem láttán, és nagyon sajnálom, hogy ilyen kegyetlenül bántam velük, miután befejeztem és kinyomtattam egy-egy képet. Újra és újra bocsánatot kértem tólük. Valóságos szörnyetegnek éreztem magam. 
Megígértem nekik, hogy a jövóben keményebben fogok dolgozni, megváltoztatom a munkamódszeremet, és igyekszem hozzájárulni az ó jólétükhöz. Mindenképpen módjuk lesz rá, hogy segítsenek létrehozni a múveimet: én állítom be a kezdeti feltételeket, de azután ók is meghozhatják a saját döntéseiket. Végül elhatároztuk, hogy a közeljövóben újból összejövünk, és megbeszéljük, mit sikerült addig elérnünk.

\section{Charles Csuri: Kitapintható mozgásérzékelés (1998)}

Hagyományos festő koromban gyakran úgy véltem, hogy az érzelmek és a mozgás fizikai érintkezés útján megvalósuló, taktilis érzékeltetése között közvetlen összefüggés van, vagyis minél határozottabbak az ecsetvonások, annál erốteljesebbek és annál mélyebbek az érzések, míg a könnyed ecsetkezelés lágy, erốtlen lélekre vall. Késóbb azonban megtanultam, hogy a múvészetben nincsenek efféle közvetlen kapcsolatok. Más dolog a tapintás útján érzékelhetô fizikai súly vagy nyomás, és megint más az érzelmek vagy a lelkiállapotok kifejezése, ami sokkal bonyolultabb és titokzatosabb. Hogyan hozza létre múalkotásait egy író, egy zeneszerzó vagy egy koreográfus? Az író szavakat használ gondolatai vagy érzelmei kifejezéséhez. Létezik a zenei hangok absztrakt kódja, és a testbeszédnek is megvan a maga nyelve. A zeneszerző vajon hallja a hangszereket és a papírra feljegyzett hangjegyeket? A koreográfus virtuális táncosok mozgását látja, érzékeli a térben?

Ma nem használok többé ecsetet, ceruzát vagy szenet a képeim létrehozásához. Mivel billentyúzetet és egeret használok, ebból az következne, hogy nem tudok sokatmondó múvészi alkotást produkálni? Én is billentyúket nyomogatok, mint egy író, de a szimbólumaim matematikai kódot követnek. Múvészként tehát csakugyan igen korlátozottak lennének a lehetôségeim, csak azért, mert logikusan és szisztematikusan kell dolgoznom? A számítógépnyelv képessé tesz a múvészi tartalom, a jelentésrétegek szervezésére és strukturálására. Sok évvel ezelốt megtanultam, hogy idôre és tapasztalatokra van szükség, amíg az ember hozzászokik egy médiumhoz és annak az eszközeihez: ez nélkülözhetetlen ahhoz, hogy megnyíljon az út a kreatív önkifejezéshez, és kialakulhasson bármifajta ritmus az alkotás folyamatában.

De hol van a spontaneitás a számítógépek kontextusában? Valóban szeretném tudni, hogy mit is kell értenünk „spontaneitás”-on. A számítógép billentyúzete vagy az egér csakugyan korlátozná a kreativitásomat, ha csak ezeknek az eszközöknek a közvetítésével tudok dolgozni? A szavak áramlásának eszméjét, ahogy az író dolgozik a billentyúzet közvetítésével, könnyebben megértjük. Fel tudjuk fogni, hogy abban a folyamatban, ahogy az író összefúzi a szavakat, lehet valami érzelmi súrítés. Ott van azután a zeneszerzó és a koreográfus, akik papíron, tollal és tintával rögzítik a múveiket. A spontaneitást az ő esetükben a szimbólumok papírra való gyors feljegyzése biztosítaná? Tudjuk, hogy a festók ecsetje és az érzelmeik között is van valamiféle kapcsolat. A kreativitás, az alkotás folyamata azonban sokkal bonyolultabb, mint a fizikai kontaktus és a kinesztézis külsố megjelenése.

Múvészi mondanivalóm közvetítô közege most a számítógép. Hozzászoktam egy bizonyos tempóhoz és dinamikához, ahogy matematikai értékeket állítok be a para-

"Tactile kinesthesis. http://www.csurivision.com/charles-csuri/digital-art-3_0.php 
méterek terébe. Ennek is megvan az intellektuális ritmusa. Valahol a háttérben ott bujkálnak a múlt nagyszerú múvészetével kapcsolatos ismereteim és érzéseim. Amikor matematikai értékeket állítok be, a tudatom a színek és a fény mintáiként érzékeli a választási lehetôségeket. Az objektumok közötti kapcsolatokat olyan transzformációkként látom, amelyek a pozíciót, a forgásirányt és a skálát is magukban foglalják. Magasabb szinten ez az algoritmusok, függvények és eljárások egész folyamát jelenti. Mindezt pixelekké vagy ecsetvonásokká fordítom át. A kifejezés spontaneitása az elmémben van, nem pedig az ujjaimban. Esztétikai érzékenységem a számítógépi nyelvbe ágyazódik be. A számítógép válaszol az instrukcióim által közvetített lelkiállapotomra és az érzéseimre. Valós idejúi visszacsatolást nyújt: látom a készüló képemet a monitoron. Látszólag a képernyő vált az új vásznammá. Előre-hátra lépkedve dolgozom, változtatgatva a kapcsolatokat az objektumok, a színek és a textúrák között egy világméretú térben. Végül majd eldöntöm, hogy ez múvészet-e.

\section{Charles Csuri: Visszatekintések, tünődések, ars poeticák ${ }^{7}$}

Tízéves koromban kezdtem érdeklődni a múvészetek iránt. A bátyám biztatására múzeumokba jártam, és különféle órákat látogattam, késóbb pedig múvészetet tanultam az Ohiói Állami Egyetemen. Jó barátságba kerültem Roy Lichteistein pop-art múvésszel, s 1955 és 1965 között többször is kiállították a festményeimet New York Cityben.

1955-ben egy másik jó barátom, egy mérnök ismertetett meg a számítógépekkel. Ettól kezdve tíz éven át gyakran együtt iszogattunk, és sokat beszélgettünk a számítógépekról és szerepükról a jövóben. Grafikai alkalmazásuk gondolata sohasem merült fel, mivel nem voltak grafikus outputberendezések. A számítógépet eleinte csak szöveggyártó vagy számcsócsáló gépezetnek tekintettem, de biztos vagyok benne, hogy ezek a beszélgetések közrejátszottak abban, hogy nagyra értékeltem és megértettem a múködését. Eljutottunk arra a fokra, hogy a számítógépben megláttuk az intellektuális, elméleti és fillozófiai perspektívát is. Azután 1965-ben láttam egy arcról készült számítógépes grafikát, amelyhez outputberendezésként egy távirányítású elektromos írógépet (flexowriter) használtak fel. Az arcról készített fényképet manuálisan digitalizálták a kontúrokon belüli régiók fedettségi értékének becslései alapján. A számítógép széttördelte a képet a szürke különféle fokozataira, és meglágyította a kontúrokat, szinte folyamatos átmenetet biztosítva a tónusok között. Amikor ezt megláttam, rögtön tudtam, mit kell tennem: meg kell tanulnom, hogyan lehet programozni a gépet, és sok technikai ismeretre kell szert tennem. Mindez - a mérnök barátommal több mint tíz éven át folytatott beszélgetéseknek köszönhetôen - izgalmas és vonzó feladatnak túnt

\footnotetext{
7 2007-ben január és március között számos levelet váltottam Charles Csurival, ennek során a kutatói kérdésekre egyre hosszabb, cgyre több érdekes személyes részletet felfedő válasz érkezett. Néhol már-már kis miniesszé kerekedett egy-egy gondolatból. A visszaemlékezés folyamatosságát megtörố kérdéseket elhagyva elôször négy levélból komponáltunk egységesnek ható, kerek szöveget, majd az egyes gondolatokat, témaköröket kiegészítô további részleteket válogattunk hozzá három korábbi interjúból, amelyeket Arthur Efland (Cybernetic Serendipity, 1968), John Staudhammer (Computer Graphics and Applications, 1990) és Robert Butche (életútinterjú az Oral History archívum számára, 2003) készített vele. Valamennyi szöveg megtalálható Csuri honlapján. Így elveszett ugyan az interjú „egysége”, de a nyereség sokkal nagyobb: a részletekból Csuri teoretikus világának teljesebb áttekintését lehetett felépíteni - Z. Karvalics Laíszló.
} 
számomra. Sokat segítettek azok a múszaki szakemberek, akik akkoriban ott dolgoztak az Ohiói Állami Egyetemen, ahol múvészetet tanítottam. Azt hiszem, felkeltette az érdeklődésüket, hogy egy múvész meg akar ismerkedni a számítógépekkel. Történetesen a megfelelő helyen voltam a megfelelố idóben.

1968-ban a barátaim bátorítottak, hogy nyújtsak be pályázatot pénzügyi támogatásért az Országos Tudományos Alapítványhoz (National Science Foundation, NSF). Nem volt semmiféle tudományos képzettségem, és elég elképesztố gondolat volt, hogy az NSF esetleg támogatna, de a barátaim szerint volt néhány jó ötletem. Akkoriban volt afféle pionírszellem az alapítványnál: elő akarták segíteni, hogy a nagyobb közönség is megismerje, mire képesek a számítógépek. Hazárdjáték volt, de nyertem: megkaptam a támogatást. Mivel bebizonyítottuk, hogy jó kutatásokat tudunk végezni, az NSF további húsz éven keresztül folyamatosan támogatta a munkámat. A háttérismereteim kérdése egy idó múlva feledésbe merült.

Attól tartok, nem túl sok bepillantást tudok nyújtani abba az intellektuális légkörbe, amely az 1960-as években az egyetemen uralkodott. Azok a nagyobb kérdések, hogy a számítógép hogyan fogja megváltoztatni az információfeldolgozás, a kutatás vagy a múvészi alkotás világát, csak késóbb merültek fel. A társadalomtudósok képesek lehettek eloóre látni az információs technológia által a kultúrára gyakorolt hatásokat, mi azonban, akik a felhasználói közösséghez tartoztunk, nem kaptunk semmiféle támpontokat vagy történelmi referenciákat arra nézve, hogy az informatika fejlôdése mi mindent hozhat magával. A legtöbben igen pragmatikus attitúddel viszonyultunk a számítógéphez, és csupán arra koncentráltunk, hogy az miként segítheti a munkánkat a saját érdeklôdési területünkön.

Amikor az 1950-es évek közepén megismerkedtem a számítógéppel, a tipikus kérdéseket tettem fel: Mi ez? Hogyan múködik, vagyis hogyan „gondolkodik”? Micsoda valójában egy számítógépes program? Lehet vajon képeket is létrehozni vele? (Abban az idóben erre még nem volt lehetốség.) A számítógép problémamegoldásra vagy kutatásra történő felhasználása forradalmi gondolat volt. Évekig tartott, amíg ennek valamennyi következményét felfogtam. Érdekeltek a mesterséges intelligenciával és a számítógéppel mint „legfóbb tanácsadóval” kapcsolatos elgondolások. Érdeklődésem fóleg arra irányult, hogy a számítógép milyen hatást gyakorolhat a saját speciális terïletemre, és a legtöbb kollégámat szintén az érdekelte a legjobban, hogy ók maguk mire tudják felhasználni a gépet. Miután 1963-ban és 64-ben kiderült, hogy a számítógépek képeket is tudnak produkálni, felismertem a vizualizációs technológiák felhasználási lehetôségeit számos tudományterületen. Minden olyan új volt, hogy a legtöbben nem láttuk át, milyen hatást gyakorolhatnak a számítógépek a társadalomra. Több év telt el, mire elgondolkodtam, és feltettem magamnak a kérdést: Mit jelent mindez? Hogyan befolyásolja a számítógép az életünket, és mint emberek milyenek leszünk vajon a jövóben?

Amikor 1964-ben rendszeresen dolgozni kezdtem a számítógéppel, az egyetemünkön csak egyetlenegy gép volt. Ez még a lyukkártyák, a Fortran-és Assembler-s szintú programozás korszakában volt. A számítógépterem mindenkinek a találkozóhelyévé vált, aki kutatásokat végzett. Visszatekintve, számomra mint múvész számára nagyszerú környezet volt, mivel ott tudósokkal és matematikusokkal találkozhattam. 
A számítógépes grafika teljesen új terület volt: egyszerúen nem voltak elérhetố kereskedelmi szoftverek - ezek csak tizenöt évvel késóbb jelentek meg. A számítógépes múvészet és grafika terén mindent nekünk magunknak kellett kitalálni. Óriási kihívás volt mindannyiunk számára, hogy az információ feldolgozásával kapcsolatos fogalmainkat a számítógép képességeinek kihasználása érdekében algoritmusokká, szoftvereszközökké és stratégiákká fordítsuk le.

A számítógép szerepe társadalmunkban ma nyilvánvaló. Több mint negyven évvel ezelótt azonban csupán az egyetemi körökben tudományos kutatással foglalkozó szakemberek látták meg a benne rejlő lehetôségeket. A 60-as évek közepén még nem volt internet, és a számítógépes múvészetról szinte lehetetlen volt bármit is publikálni. Három éven keresztül próbálkoztam egy cikk megjelentetésével, amit a számítógépes grafika és a múvészetek témájáról írtam (Computer Graphics and The Arts), míg végül az International Journal for Electrical Engineering leközölte. A múvészetek területén valóban elszigetelten dolgoztam. Semmit sem tudtam arról, hogy mi történik az ország más részein, Németországban, Japánban vagy másutt. Egy „számítógéppel dolgozó múvész" már önmagában is botrányos jelenség volt. Ha nem lettem volna végleges állásba kinevezett professzor, elküldtek volna az egyetemról. Ma az emberek nemigen tudják felfogni, hogy 1964-ben még senki sem dolgozott számítógéppel, akinek múvészeti képzettsége volt. Azt hiszem, ez igaz világviszonylatban is. Azelött sok tudós múvésznek hitte magát, ha egy tervrajzot le tudott rajzoltatni a géppel. Mindenütt ellenségesség és elutasítás volt érezhetô, és ostobaságnak túnt az a gondolat, hogy egy múvész számítógéppel dolgozzon. Nekem az volt a szerencsém, hogy elismert múvésznek számítottam, akinek kiállításai voltak New York City múvészeti galériáiban. A múvészeti tanszékról így is távoznom kellett a kollégáim elutasító attitúdje miatt. Átnyergeltem a múvészeti oktatás területére, ahol tapasztalható volt legalább némi intellektuális érdeklődés a számítógépek oktatási alkalmazásai iránt.

A saját érdeklôdési területem igen szúk volt, és csupán tudósokkal beszélgethettem a munkámról. Megértettem, hogy ez milyen következményekkel jár számomra, küilönösen ami magával a múvészeti alkotással kapcsolatos gondolkodásomra gyakorolt hatását illeti. Láttam, hogy az, amivel foglalkozom, hogyan érintheti a formatervezóket és az építészeket, s tudtam, hogy a múvészet világa soha többé nem lehet már ugyanaz. Múvészként sok tekintetben a túlélésért küzdöttem, amikor egyebek között a szoftverekról, az algoritmusokkal kapcsolatos fogalmakról és a mesterséges intelligenciáról tanultam.

Mint hagyományos múvész, aki azelốtt elsôsorban festményeket alkotott, felfedeztem egy teljesen idegen tájat, ahol a képalkotásra vonatkozó új gondolatokkal, kifejezésekkel és fogalmakkal találkoztam. Könnyú lett volna teljesen összezavarodni a céljaimat illetôen, és feladni az egészet. Ami ma nyilvánvalónak túnik, 1964-ben radikális gondolat volt. A taktilis-kinesztétikai megközelítésról áttérni a számítógépes képgenerálásra drámai változást jelentett. Múvészi világom fenekestül felfordult. Mivel nem voltak kereskedelmi szoftverek, a képek előállítására alkalmas újabb és újabb eszközök kifejlesztése komoly kihívást jelentett. Nagyon sokat kellett tanulnom. A bölcsészkari kollégák úgy gondolták, hogy elment az eszem. Valóban ellenségességet és elutasítást érzékeltem mindenütt.

Mivel azonban türelmetlenül vágytam céljaim elérésére, elkezdtem toborozni olyan embereket, akik segíthetnek nekem. Ezeket a matematikusok, a tudósok és a 
programozók között találtam meg. Azon kaptam magam, hogy állandóan megpróbálom elfogadtatni másokkal is azt a gondolatot, hogy a számítógépet grafikai alkotásra használjuk fel. Volt bizonyos vízióm a jövoóról, és nagyon igyekeztem eljutni oda. Az eredményeim nagy részét a programozásban segítséget nyújtó és a terveim iránt érdeklődô emberek jóakaratának köszönhetóen sikerült elérnem.

Olyan sokat kellett tanulnom, hogy nem volt idốm hátradólni, és elgondolkodni mindennek a messzebbre mutató következményeirôl. Korán megértettem azonban a számítógépes grafika jelentôségét a vizuális megjelenítés terén számos tudományágban, az oktatásban és a múvészetekben. Ténylegesen éppen ezeknek a meglátásaimnak köszönhető, hogy az NSF számítógép-tudományi szakosztálya támogatta a vizuális megjelenítés és a számítógépes grafika területén folytatott kutatásaimat. Múvészek számára az alapítvány sohasem nyújtott támogatást. Az egyik programigazgató azt mondta, hogy azért támogatják a projektjeimet, mert több fantáziát látnak bennük, mint a legtöbb számítógéptudós munkájában. Nem akarok ebból nagy ügyet csinálni, de az NSF húsz éven keresztül támogatta a számítógépes grafikai alapkutatásaimat. Ez több millió dollárt jelentett. Félretettem a múvészi karrieremet, és az egyetemen létrehozott számítógépes grafikai kutatócsoport (Computer Graphics Research Group) igazgatója lettem - véletlenül úgy hozta a sors, hogy dr. James Hahn, a George Washington Egyetem számítógép-tudományi tanszékének vezetôje a saját doktori diszszertációjához végzett kutatásai során együtt dolgozott velem. Kutatócsoportom számos problémát megoldott a mesterséges intelligencia, az animációs nyelvek, a kinematika és a mozgásábrázolás, valamint általában a számítógépes grafika területein. Késóbb úgy alakult, hogy a múvészeti oktatás mellett állást kaptam a számítógép-tudományi karon is. Kutatási tapasztalataim sokat segítettek annak megértésében, hogy a számítógépes grafika hatást fog gyakorolni az egész társadalomra. Azokban a korai években sok mindent megértettem, de nem ismertem fel teljes mértékig, hogy ez milyen messzire fog vezetni egész kultúránk alakításában. Visszatekintve könnyú lenne kitalálni valamiféle jövôvíziót, amelynek az elérésére törekedtem, de sok tekintetben magam sem tudtam, hová akarok vagy hová fogok eljutni. Olyan volt, mint behatolni egy teljesen ismeretlen területre, és elgyönyörködni az ott levő életformákban. Minden igen gyorsan történt, és mindig volt valami új, amit meg kellett tanulni.

A média által a kultúránkra gyakorolt hatásokról igen sok könyvet és tanulmányt írtak már. A média befolyásolja politikánkat, értékeinket és igényeinket. A tévében közvetített hírek és tudósítások pillanatképeket mutatnak a valóságról. Az emberek általában körülbelül harminc másodpercen keresztül tudják összpontosítani a figyelmüket valamire - ennyi a tévéreklámok átlagos hossza. Engem nagyon elkedvetlenít a legtöbb ember hozzáállása a politikához vagy a világ eseményeihez: ha azok nem érintik óket közvetlenül, közömbösek maradnak, vagy bizonyos védekezô-elutasító attitüdöt vesznek fel. Vegyük például az iraki háborút! Ha minden fiatalembernek be kellene vonulnia a hadseregbe, és a családokat közvetlenül fenyegetnék a háború veszélyei, ez az ország már régen véget vetett volna az iraki hadviselésnek. Mivel azonban a hadseregünk önkéntesekból áll, viszonylag kevés ember ad hangot az Irakkal kapcsolatos aggodalmainak. 
Az információs társadalom robbanásszerúen bővül az internet útján, s ennek a hatásai beláthatatlanok és ugyanakkor rémisztőek lesznek. A fiatalabb generáció máris természetesen használja a számítógépes technológia különféle szerkentyúit. A technológia megkönnyíti az emberek számára, hogy kapcsolatot teremtsenek, és megoszszák egymással az információkat. Sokféle szinten megvalósult a tapasztalatok és a tudás megosztása. Könnyebb kapcsolatban állni egymással. Ennek szakmai szempontból is értéke van, és megadja az embernek azt az érzést, hogy részt vesz az események fósodrában. A Secondlife.com virtuális valósága a kommunikáció új lehetôségeit tárja fel az interneten. Több mint hárommillió előfizetôje virtuális bevásárló körutakra indul, ingatlanokat árul, és személyre szabott környezeteket vagy helyeket teremt, ahol megjelenik. Sokan úgy vélik, hogy az internet fejlődése ezzel új fázisba lép, és a növekedés továbbra is gyors lesz. Valóban értékes és jelentôségteljes interperszonális kapcsolatok azonban csak korlátozott mértékben jönnek létre. Az olyan technológiai megoldások, mint az e-mail üzenetváltás vagy akár a telefonbeszélgetés, nem a legjobb helyettesítói a közvetlen emberi érintkezésnek. Korlátok állnak azeloótt, hogy mit érhetünk el távjelenléttel. Testbeszéd, szemkontaktus és érintés nélkül nehezebb az emberek számára valóban sokat jelentô kapcsolatokat teremteni. Az efféle interakció szüikséges a bizalom kialakulásához. Az emberek sokszor talán szívesen is veszik, hogy a technológia korlátokat állít valódi érzelmeik és egymáshoz fúzôdô viszonyuk kifejezésre juttatása elé. Végeredményben azonban mindannyiunknak olyan kapcsolatokra van szükségünk, amelyek célt és értelmet adnak az életünknek.

A gyors változások, múló szeszélyek és divatok sodrába került társadalomban élünk. A média, különösen a tévé nagyban befolyásolja, hogy mit várunk a jövôtoól. Több mint negyven éve dolgozom számítógépekkel, és gyakran gondolok arra, hogy személy szerint nekem mint múvésznek ez valójában mit is jelent. Hogyan változtam meg? Valóban jobb múvész lettem attól, hogy technológiai eszközökkel fejezem ki magam? A technológia alkalmazása vajon megváltoztatta a múvészetról alkotott felfogásomat? Mások lettek a múvészek alapvetô problémái? Az új kifejezési lehetôségek gazdagították vajon a kultúrát a múivészetek viszonylatában? A válasz: nem. A tévé és a mindenféle képekhez való könnyúi hozzáférés sok szempontból csupán növeli a zavart azt illetôen, hogy mi a múvészet. Mi tekinthetô sokatmondó múalkotásnak? Mindezekkel kapcsolatban naponta kétségeim támadnak. A számítógépes múvészet világában olyan emberek tevékenykednek, akik sokféle algoritmikus múalkotást és virtuális valóságot hoznak létre. Azt hiszem, eltúlozzuk ezeknek a fontosságát. Az algoritmusok csupán eszközök. Megtestesíthetnek bizonyos elméleteket, de akkor is csak eszközök. A „virtuális valóság” ma divatos kifejezés, de valójában régi gondolat. Platón a barlang allegóriájában virtuális valóságról beszél. Azt hiszem, hogy én a magam részéról már igen régen elfogadtam a számítógépeket. A számítógépes grafika terén végzett alapkutatás tapasztalatai bepillantást engedtek abba, hogyan lehet különféle „valóságokat” megjeleníteni. Nagyra értékelem a számítógépi kódok komplexitását, a kérdés azonban továbbra is fennmarad. Múvészet ez? A múalkotásnak képesnek kell lennie arra, hogy túllépjen az elméleteken. Érzelmi töltésének összefüggésben kell állnia azzal, ami emberré tesz bennünket. A technológia hatásai folyamatosan hozzájárulnak az értékekkel és az élet értelmével kapcsolatos zavarodottságunkhoz. 
Nemrégen feltettem néhány újabb munkámat a honlapomra. Gyakran teszem fel magamnak azt a kérdést, hogy a számítógépet hogyan használhatom fel újszerú módon. Az csak idópocsékolás, ha azt utánzom, amit megtehetnék egy festménnyel is. A számítógép használata túl sok erófeszítést kíván, és korlátozza a múvész spontaneitását. Azt hiszem, hogy az olyan alapvetô kérdéseket tekintve, mint a forma és a tér felfogása, váltásnak kellett végbemennie a gondolkodásomban. A munkám technikai részletei érdekesek lehetnek mások számára is, de bizonyos mértékig mégiscsak kívüil esnek az érdeklődésük fớ irányán. Érdekes lehet azonban az is, amit leírtam arról, hogy mit akarok kifejezni a múveimmel, vagy hogyan használtam fel az internetet segítségként néhány gondolat formába öntéséhez. Bár a nyelvi kifejezés több munkával járt, számomra élményt jelentett, hogy a Google keresốprogrammal bizonyos kulcsszavak nyomába eredhettem. Felfedeztem különböző filozófusok, tudósok, misztikusok és mások megállapításait a térról, az idốról, a formáról, a valóságról stb. Mindezt nagyon hasznosnak találtam ahhoz, hogy néhány újabb múvel kapcsolatban megfogalmazhassam a következóket:

A forma és a tér jelentését illetôen van néhány kérdés, amelyek folyamatos kihívást jelentenek a filozófusok, a fizikusok és a múvészek számára egyaránt. Mi a forma és mi a tér? A keleti filozófiában néha azzal az állítással találkozunk, hogy a forma üresség és az üresség forma. Bonyolult kérdés, hogy mit érzékelünk és mit élünk át valóságként. A valóság folyamatosan változik az idóben. A képeim bizonyos mértékig a bizonytalanságomat szimbolizálják arra nézve, hogy mi a forma és mi a tér. Ezek kettôs értelmezése nagy szerepet játszik a saját szemléletemben. Számomra sok minden lehet forma és tér egyaránt: pontok halmaza, egy algoritmus, bizonyos tulajdonságok, paraméterek vagy részecskék, sớt akár fényhullámok is. Múvészként a formát és a teret valamiféle dinamikus, interaktív folyamatként fogom fel. Az, hogy mit érzek térnek és mit formának, ide-oda ingadozik. A valóság ugyanannak a formának a tér által módosított különbözố reprezentációivá válik. Maga a valóságfelfogásom is állandóan változik, amikor megpróbálom eldönteni, hogy mi valóság és mi illúzió.

Múvésznek vallom magam, és szeretném látni, mire vagyok képes. Alkotómunkám személyes kielégülést nyújt számomra, ám egyszersmind „felhasználóként” is múködöm: ki akarom próbálni a szoftvereket. Szerencsére olyan helyzetben vagyok, hogy vannak körülöttem olyan szakemberek, akik speciális szoftvereket írnak a jelenségek tudományos kutatási célokra szolgáló megjelenítéséhez, és én felhasználhatom ezeket múalkotások létrehozására.

Ha nem válnak be, kérhetem, hogy javítsák ki óket. Ismét a felhasználói kalapomat feltéve, és szabadjára engedve az elmémet, hogy eljátsszon a valósággal kapcsolatos gondolatokkal (és talán hozzájáruljon a valóság humoros oldalának a megláttatásához is), képes vagyok olyan kérdéseket megfogalmazni, amelyek furcsa módon elóbbre viszik a technológiát.

Ha jól emlékszem, egy alkalommal, amikor éppen egy Steve Spencer által kifejlesztett radiozitásalgoritmussal dolgoztam, nagyon tetszett a fény és az egész megvilágítási modell, de riasztóan magasnak találtam az eljárás számítási igényeit. Azután Scott Dyer, aki a képeket soronként beolvasó algoritmusunkat írta, összejött Steve-vel, hogy 
megpróbálják egyidejúleg érvényesíteni mind a két eljárás erốsségeit, megvalósítva a globális megvilágítást nagy beolvasási sebesség mellett is.

Ennek következtében ma már az is megoldható, hogy a fényviszonyok kiszámításánál egyszerúsített tárgyakkal és kis felbontással dolgozom, és a kapott eredményeket továbbadom a sorolvasó algoritmusnak, amely kiszámolja a kép végleges, nagy felbontású változatát. Felfedeztem továbbá, hogy a radiozitásalgoritmus nem kezeli jól a sû́rú domborulatokat és a tükrözó felületeket, de ez köztudottan bonyolult probléma.

Egy más alkalommal a képfeldolgozó csomagok kifejlesztésével foglalkozó Jeff Lighttal dolgoztam együtt, és az úgynevezett edge detection (a szegélyek detektálása vagy éldetektálás), valamint a színekkel való játék segítségével megpróbáltam érzékeltetni az ecsetvonások hatását. Jeff beszkennelt egy fényképet, és úgy vélte, hogy sikerült azt olyanná tennie, mintha ecsettel készült volna. Én azonban így válaszoltam: „Ez nem olyan, mint egy olajfestmény. Hadd vegyek elő egy múvészeti albumot: megmutatom, hogy néznek ki az ecsetvonások." Kimentem a városba, és elköltöttem körülbelül száz dollárt múvészeti könyvekre.

Visszatérve így folytattam: „Nézzük meg Cézanne és Seurat múveit, lássuk van Goghot vagy Turnert!” Azután beszélgettünk az optikai színekról és a színek keveréséról, amitól azok életre kelnek. Megvitattuk, hogyan lehetne megjeleníteni az ecsetvonásokat. Azt mondtam, olyan dolgokat szeretnék, amelyek úgy néznek ki, mint a vastagon felrakott festék, az impasto az ecsetvonások nyomában.

Jelenleg olyan képeket csinálunk fényképekból, amelyek teljesen úgy néznek ki, mintha festók alkotásai volnának.

A képeimmel megpróbálok eltávolodni a számítógépes grafika tipikus plasztikai megoldásaitól és steril jellegétól. Mindig olyan képeket akartam alkotni, amelyek legalábbis első látásra - nem juttatják az ember eszébe a számítógépet, és amelyekben mindig kell lennie valamilyen sokatmondó, de nem kognitív tapasztalatot hordozó gondolatnak. A képalkotás formalista nézốpontból kevéssé érdekel. Nem sokra becsülöm a vizuális tornamutatványokat, és még kevesebbre tartom a számítógépes grafikával elérhetố speciális effektusok csillogását és ragyogását. A steril, hideg plasztikai megjelenítés nálam egyszerúen csak a kontextus vagy a háttér az emberi mondanivalóhoz.

A munkámban talán a rajzaim és festményeim személyes érzelmi töltése és a számítógéppel szintetizált környezet között megnyilvánuló feszültség a legérdekesebb. A múvészet problémája továbbra is ugyanaz: értelmezhetố jelentést hordozó struktúrát alkotni esztétikai tartalom felmutatása érdekében. A múvészetnek az emberiség nem kognitív felfogóképességéhez kell szólnia.

Általánosított szimbólumok és ikonok használatával kifejezésre kell juttatnunk egy közös, létezésünk magváig hatoló univerzális emberi élményvilágot. Ez a közös emberi tapasztalat magában foglalja a mítoszok, a mágia és a humor elemeit, sốt gyakran a szenvedés, a fájdalom és a félelem brutális valóságát is, a számítógép pedig célszerú eszköz lehet mindezek kifejezésére. Az elốttünk álló fố kihívás a számítógépes technológia emberi spiritualitásunk szolgálatában történő felhasználása. 
Hogy milyen típusú matematikát lehet alkalmazni például „kézi munka” esetén, vagyis ha mintegy „kézzel”, primitív módszerekkel akarok kiszámolni valamit - ha megbocsátják nekem ezt a kifejezést -, az attól függ, hogy mennyi ideig tart megoldani egy-egy problémát: a hagyományos módszerek túl lassúak. Azt hiszem, ezt a kérdést jobb lenne kicsit más módon megközelíteni.

Azt akarom mondani, hogy a múvész ma felhasználhat komplex matematikai apparátust és digitális számítógépeket a munkájában, mert ezeknek a struktúrája és jellemzố vonásai a problémáknak a szokásostól eltérố megközelítését kínálják fel, és ez különösen igaz az adatok ismétlődésével járó és iterációs eljárásokat igénylő problémákra, amelyeknél ki lehet használni a számítógépek múködési sebességét. Ennek a magyarázatához kissé bele kellene mennünk a technikai kérdésekbe is.

Lényegében annyit mondhatok, hogy a matematika új lehetôségeket nyit meg a múvészetek birodalmában. A háromdimenziós geometria helyett használhatunk például n dimenziós vagy százdimenziós geometriát is, amely egészen más fogalmat nyújt a formáról, és más lesz a struktúra fogalma is. Sokkal szisztematikusabb módon használhatók fel a véletlenszám-generátorok, a pontok vagy vonalak bizonyosfajta eloszlásait hozva létre, amelyek igen érdekesek lehetnek.

Azt hiszem, hogy amikor az ember úgynevezett struktúrákkal, illetve pontoknak, értékeknek, vonalaknak vagy bármi másnak az eloszlásával foglalkozik, bizonyos elóítéletekkel lát hozzá. Ez az elfogultság a múltbeli tapasztalatokon és az arra vonatkozó prekoncepciókon alapul, hogy mit szokás struktúrának tekinteni a múvészetben, az elfogultság leküzdésének egyik módja pedig az efféle rögzuilt szemléletmódtól teljesen független matematikai rendszer igénybevétele, ami lehetôséget ad az elóítéleteink miatt egyébként fel sem merülő, újszerú interpretációra.

Szeretem azt az érzést, hogy itt valamiféle igen speciális fegyelemról van szó. Valójában azt akarom mondani, hogy a döntéshozatalnak vannak bizonyos módjai, amelyek alkalmasabbak lehetnek a régieknél, továbbá bizonyára vannak olyan gondolkodási minták is, amelyek valamelyest eltérnek a problémamegoldás múltbeli módszereitól, és ez önmagában is érdekes számomra.

Amikor konvencionális módon hozok létre egy festményt vagy egy rajzot, rendszerint gondot okoz a közvetító közeg. Meg kell határoznom, hogy a kép egyes részei szürkék, feketék vagy éppen fehérek legyenek-e. Ha viszont bizonyos matematikai arányokkal dolgozom, akkor eljátszhatom a számokkal, és végül a színek, az értékek és a vonalak bizonyosfajta eloszlásait produkálhatom, amelyek éppen olyan érdekesek, sốt talán még érdekesebbek, mint ha hagyományos módon dolgoztam volna, és pontosan eloore láthattam volna az eredményt.

Ebben talán senki más nem lelné örömét, de én egyszer készítettem egy bögölyról egy rajzot, amelyet sikerült betennem a számítógép memóriájába, majd úgy döntöttem, hogy kétszázötven böglyöt akarok megjeleníteni egy négyszögletes térben. Nem akartam fáradni azzal, hogy mindegyiket külön megrajzolom, és alighanem túlságosan 
terhes lett volna számomra kétszázötven alkalommal eldönteni, hogy pontosan hová is tegyem óket.

Így tehát ezt a döntést egy véletlenszám-generátorra bíztam, engedve, hogy az határozza meg a böglyök eloszlását a térben. Rábíztam továbbá az elhelyezkedési szögüknek a meghatározását is. Végül úgy döntöttem, hogy még érdekesebb lenne, ha különféle méretú böglyök lennének a képen, tehát elindítottam egy játékot, amelyben a véletlenszám-generátor négy vagy öt különféle méretú böglyöt produkál.

Végül a véletlenszerú eloszlás, a véletlen elhelyezkedés és a véletlenül adódó méretek kombinációjához jutottam, és az eredmény meglehetôsen érdekes lett. Tényleg nem hinném, hogy lett volna türelmem kétszázötvenszer megrajzolni a böglyöt különféle méretekben - bele is bolondultam volna. Ez a része a dolognak tehát különösen kellemes volt, de van ennek egy másik aspektusa is. Az, hogy történetesen éppen egy böglyöt találtam lerajzolni, bizonyára nem valami mélyenszántó gondolat, másrészt azonban ez talán mond valamit magáról a számítógépról, és arról az egész problémakörról is, amely a ,bogarakkal” (vagyis a programhibákkal) és azoknak az eltávolításával függ össze. ${ }^{8}$ Talán ez is bizonyos üzenete lehet a képnek. Eléggé abszurd ötlet persze éppen egy bögöly képét használni fel ennek a kifejezésére. Valahogy sajnálom a legyeket: eltúnóben vannak a kultúránkból.

${ }^{8}$ Lefordíthatatlan szójáték. Az eredetiben: „...this has a comment to make about the computer itself and the whole business of bugs and debugging”. - A ford. A szó eredete azonban meg is magyarázza a kapcsolatot: a számítástechnika elektroncsöves höskorában valóban a gépekbe berepülő legyek okoztak programhibákat. - Z. K. L. 